\title{
Roles of larval behaviour and microhabitat traits in determining spatial aggregations in the ascidian Pyura chilensis
}

\author{
Patricio H. Manríquez ${ }^{1,2, *}$, Juan Carlos Castilla ${ }^{2}$ \\ ${ }^{1}$ Instituto de Biología Marina 'Dr. Jürgen Winter', Laboratorio de Recursos Acuáticos de Calfuco, \\ Universidad Austral de Chile, Casilla 567, Valdivia, Chile \\ ${ }^{2}$ Center for Advanced Studies in Ecology \& Biodiversity, Facultad de Ciencias Biológicas, Pontificia Universidad Católica \\ de Chile, Casilla 114-D, Santiago, Chile
}

\begin{abstract}
The large edible ascidian Pyura chilensis Molina, 1782 is a sessile suspension feeder that occurs in intertidal and subtidal habitats along the Chilean and Peruvian coasts. In these habitats the species, although solitary, is commonly found in highly aggregated assemblages and is seldom isolated. The results of a study to determine whether the observed field aggregations could be explained by larval behaviour, microhabitat with quiescent hydrodynamics, or both, are reported. Our laboratory experiments showed that $P$. chilensis larvae have a short pre-settlement period when maintained in the presence of artificial substratum conditioned with adult conspecific extract. Moreover, $P$. chilensis larvae tended to settle in shaded areas. In the control treatment without conspecifics, or in illuminated areas, low numbers of $P$. chilensis settlers were found. In a 5-armed radial maze, under still water and low seawater flow regimens, larvae of $P$. chilensis tended to swim toward and settle in chambers that contained water in which conspecific adults had been placed. In the field, we tested the hypothesis that larval settlement in $P$. chilensis differs depending on microhabitat traits such as water flow, mechanical disturbance and light intensity. We conducted quadrat sampling on low rocky platforms in contrasting microhabitats, such as around holdfasts of the kelp Lessonia nigrescens, kelp whiplash zones and between holdfasts. The majority of $P$. chilensis settlers were found on top of conspecific adults inhabiting shaded microhabitats and around kelp holdfasts. These results suggest that protected habitats and chemical cue-mediated larval response to waterborne conspecifics during the settlement period contribute to the formation of intertidal and shallow subtidal aggregations of $P$. chilensis. Given that the edible ascidian $P$. chilensis supports an important small-scale fishery and hosts an important associated community of macro- and micro-invertebrates, we suggest that our results should be considered when determining fisheries regulatory and management practices for this species.
\end{abstract}

KEY WORDS: Microhabitat $\cdot$ Settlement $\cdot$ Waterborne cues $\cdot$ Water flow $\cdot$ Mechanical disturbance Ascidians

Resale or republication not permitted without written consent of the publisher

\section{INTRODUCTION}

In numerous sessile marine invertebrates, dense aggregations of conspecifics have been regarded as the result of selective larval behaviour at settlement, passive drift as a result of microhabitat hydrodynamic conditions, or a combination of both (Pawlik 1992). Set- tlement preferentially on or near conspecific adults is common among benthic marine invertebrates (Pawlik 1992). The aggregate distribution in these species could also be the result of preferential settlement of larvae in response to conspecific cues. However, in order for an aggregation to become established, some individuals must have initially settled in a suitable 
habitat devoid of conspecifics. In ascidians, light and gravity provide the primary sensory cues for tactic orientation during dispersal (Svane \& Young 1989). However, waterborne chemical cues may also influence larval settlement patterns (Svane et al. 1987, Svane \& Young 1989). Gregarious behaviour is an important structuring process in many marine communities, and has been linked to larval settlement in bryozoans (Ryland 1974), polychaetes (Toonen \& Pawlik 2001), molluscs (Daume et al. 1999), echinoderms (Pearce \& Scheibling 1990), barnacles (Knight-Jones 1955) and ascidians (Young 1988). Predation, competition and disturbance have been identified as factors that potentially affect survival of early post-settlement juveniles of sessile benthic invertebrates such as barnacles, bivalves and ascidians (Gosselin \& Qian 1997, Hunt \& Scheibling 1997). Environmental heterogeneity, such as crevices with reduced local water motion, may contribute to aggregated distributions in invertebrates such as barnacles (Walter \& Wethey 1996). Similarly, a reduction of the water movement by kelp holdfasts and canopy algae (Muñoz 1991, Heiss et al. 2000) and the physical abrasion or mechanical disturbance of sweeping kelp fronds (Santelices \& Ojeda 1984) could also influence the establishment of intertidal invertebrates.

Pyura chilensis is a large, edible, solitary ascidian that is found in low intertidal to subtidal rocky habitats along the Chilean and Peruvian coasts (Vásquez 1983, Davis 1995). This ascidian is one of few benthic invertebrates for which management plans have been proposed to authorities by small-scale fisheries organisations in Chile (Castilla \& Defeo 2001). Therefore, improved scientific knowledge is needed by policy makers in order to ensure sustainable harvesting of $P$. chilensis. This ascidian is a broadcast spawner with tadpole larvae that probably disperse short distances because they can only swim for a few hours before settlement (Cea 1969, Manríquez \& Castilla 2005). Previous studies have found that $P$. chilensis successfully settle into experimental and artificial substratum (Ambler \& Cañete 1991, Valdivia et al. 2005). However, in the low rocky intertidal fringe (Castilla 1981), the ascidian forms clumps of individuals tightly attached to one another, and cemented to the substratum, in crevices and shallow rocky depressions. Subtidal populations of this species cover large areas with conspicuous aggregations of 1000 ind. $\mathrm{m}^{-2}$ (Davis 1995). The high structural complexity of their tunic and the interstitial spaces in clumps of $P$. chilensis provide a sheltered microhabitat in the intertidal and subtidal zones for $>60$ species of macroinvertebrates, such as peracarids (Sepúlveda et al. 2003), the mussel Brachidontes granulata, recruits of the gastropod Concholepas concholepas and the edible sea urchin Loxechi- nus albus among others (Zamorano \& Moreno 1975, P. H. Manríquez pers. obs.). Small recruits of $P$. chilensis have also been found associated with the tunic of older individuals (Cea 1969, Davis 1995), which may explain the origin of clumps in this species.

There is good evidence that several species of invertebrate larvae use cues for orientation and navigation at small spatial scales in order to find suitable settlement sites (see Kingsford et al. 2002 for a review). In ascidians, morphological and sensory ability to respond to environmental cues has been demonstrated in terms of behaviour and physiology (Svane \& Young 1989, Vásquez \& Young 1996). The main objective of this study was to investigate, under laboratory conditions, the role played by chemical cues under different flow regimes in determining gregarious settlement in Pyura chilensis. In addition, in intertidal microhabitats, we evaluated abundance and survivorship of $P$. chilensis settlers with contrasting levels of physical disturbance that may modulate the formation of $P$. chilensisclumped intertidal populations.

\section{MATERIALS AND METHODS}

Laboratory experiments. Experiments were conducted at the Estación Costera de Investigaciones Marinas (ECIM), Las Cruces, central Chile. Adult specimens of Pyura chilensis were collected from a rocky intertidal area at Pichilemu $\left(33^{\circ} 14^{\prime} \mathrm{S}, 72^{\circ} 01^{\prime} \mathrm{W}\right)$. At ECIM, the ascidians were maintained in 5001 aquaria in flowing seawater until the begin of the experiments. Tadpole larvae were obtained in the laboratory by manipulated fertilisation using eggs and sperm removed from gonoducts of freshly collected adults (Manríquez \& Castilla 2005).

Chemical orientation cues. To investigate the role played by chemical cues in determining settlement preference in Pyura chilensis, we used a specially designed experimental array (Fig. 1) with a clear Plexiglas radial maze $(60 \mathrm{~cm}$ wide $\times 20 \mathrm{~cm}$ high, wall thickness $5 \mathrm{~mm}$ ). The apparatus was divided into 5 equally sized radial chambers separated by vertical partitions. The radial chambers were subdivided into 3 concentric sections. The external and middle sections were connected by a circular aperture covered with $250 \mu \mathrm{m}$ mesh that allowed circulation of water between the sections but prevented larval access. Five sliding doors allowed water to flow from the external to the central section of the maze. An outflow tube, $15 \mathrm{~cm}$ high, $2.0 \mathrm{~cm}$ in diameter and made of PVC, was located in the central section and allowed water to drain from the maze when running seawater was used as an experimental variable. A piece of $250 \mu \mathrm{m}$ mesh was placed at the top of the outflow tube to prevent larvae being lost 
(a)

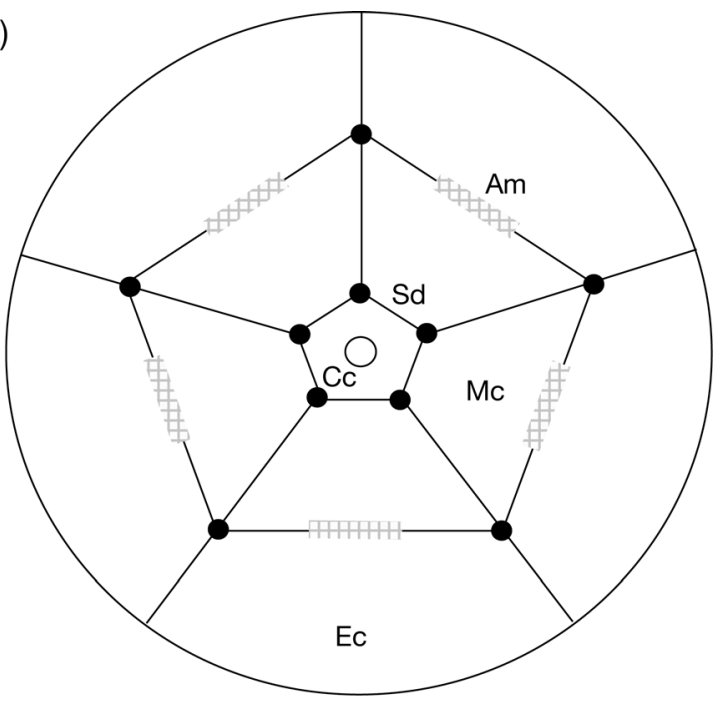

(b)

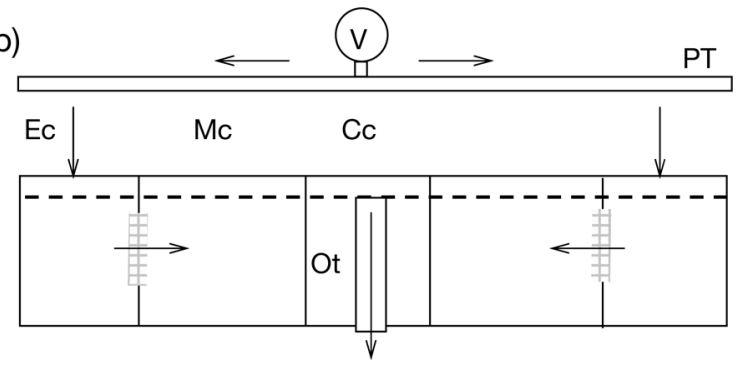

Fig. 1. (a) Plan of the 5-arm radial maze (not to scale), showing position of the 3 concentric chambers, the circular apertures with mesh (Am) connecting the external chamber (Ec) and the middle of settlement chambers (Mc), and the sliding doors (Sd) around the central chamber $(\mathrm{Cc})$. (b) A lateral schematic view of the 5-arm maze shown together with the PVC tube that delivers seawater into each external chamber (PT), the adjustable valve (V) used to regulate the flow rate, and the outflow tube (Ot) that drains seawater from the maze. Arrows indicate the directions of seawater movement. In the middle sections, pieces of nettlon net and acetate sheets that cover all the walls of the sections provide standard settlement surfaces

with the drained water. Using this apparatus we conducted 2 experiments. In the first design, we placed clumps of several adult specimens of $P$. chilensis in all the external sections. In the second design, we placed the specimens in 3 external sections only. The remaining 2 external sections were empty. In the middle sections, $15 \times 25 \mathrm{~cm}$ pieces of nettlon net $\left(\sim 200 \mathrm{~cm}^{2}\right)$ and acetate sheets covering all the walls of the sections were used as settlement surfaces. Five apertures made in a PVC tube placed above the maze delivered filtered seawater $(5 \mu \mathrm{m})$ into each of the external chambers of the radial maze, generating a net water current towards the central outflow section. The flow rate was regulated with an adjustable valve and measured with a volumetric cylinder at the outlet to the nearest
$0.1 \mathrm{~cm} \mathrm{~s}^{-1}$. At the start of the experiments, we placed a group of $~ 500$ larvae in the central section and acclimatised them for 5 min before opening the sliding doors to the external sections. Larvae were exposed to the water contained in the central section for $2 \mathrm{~h}$. We conducted these 2 experiments with 3 flow treatments: still water, low (1 to $3 \mathrm{~cm} \mathrm{~s}^{-1}$ ) and high ( 21 to $30 \mathrm{~cm} \mathrm{~s}^{-1}$ ) flow, with 4 replicate runs for each treatment. All experiments were conducted in darkness, and the number of settlers on the settlement surfaces was evaluated after $48 \mathrm{~h}$. A 1-way ANOVA followed by Tukey-Kramer HSD post hoc tests determined whether total number of settlers varied among the 3 water flows examined. A 2-way ANOVA on number of settlers determined whether settlement differed within each water flow as a function of presence of conspecifics. When data showed evidence of heterogeneity of variance, making the variance unsuitable for ANOVA, we used Taylor's power low to provide an appropriate transformation based on the slope of log-transformed plots (Legendre \& Legendre 1998). ANOVAs were then conducted on log-transformed data after visual inspection of residuals, and Cochran's $C$-tests indicated normal distributions and homogeneity of variance. For experiments in which flow and presence of conspecifics were investigated simultaneously, both variables were treated as fixed factors.

Pre-settlement period. In order to investigate the effect of chemical cues associated with conspecifics on swimming time in newly hatched Pyura chilensis tadpoles, we randomly assigned 10 replicate groups of 150 larvae to Petri dishes that contained the experimental substrata. Two contrasting experimental substrata were used in the experiment: (1) a circular acetate sheet that had been pre-conditioned for 2 mo in running seawater containing adult specimens of $P$. chilensis (hereafter adult-conditioned acetate sheets) and (2) a conditioned acetate sheet that had been maintained in running seawater for the same period (hereafter unconditioned acetate sheets) in the absence of adult specimens. In each experiment the acetate sheet completely covered the bottom of each Petri dish. Once groups of larvae were assigned to the Petri dishes, the number of swimming larvae was evaluated at pre-determined times (i.e. 0.17, $0.33,0.5,1,2,4,12,24$ and $48 \mathrm{~h})$. Average pre-settlement time periods were measured in 50 larvae exposed to unconditioned and conditioned substratum, and then compared using a Student's $t$-test on log-transformed data.

Conspecifics as natural settlement substrata. In order to investigate selective settlement of Pyura chilensis larvae on adult conspecifics, we randomly assigned 5 replicate groups of 150 larvae to 2 experimental treatments in $1000 \mathrm{ml}$ glass beakers filled with $0.45 \mu \mathrm{m}$ filtered seawater. In the first experimental treatment we included a living adult specimen of 
P. chilensis. The second experimental treatment included a tunic dissected from a live specimen a few minutes prior to the experiment. In each beaker we placed 2 conditioned acetate sheets that had been maintained in running seawater for 1 mo without adult specimens of $P$. chilensis. These included a rectangular sheet placed adjacent to the lateral wall and a circular sheet that covered the bottom. The experiment ran for $72 \mathrm{~h}$ before the natural and artificial substrata were removed and examined with a stereo-microscope to assess the number of larvae settled either on the tunic or on the acetate sheets. We also counted larvae that had not settled or had been eaten, by sampling the seawater and the faeces of ascidians. In order to compare numbers of settlers in each treatment, we standardised the number of settlers by available surface area of tunic or acetate. The surface area of potential settlement space on each living ascidian was estimated by assuming a cylindrical shape and measuring the height and diameter of each individual. The larval fates in experiments were compared by 1-way ANOVA followed by Tukey-Kramer HSD post hoc tests.

Light and larval settlement. Larval responses to different light intensities were studied in a series of Petri dish experiments. We assigned 25 replicate groups of 30 larvae to Petri dishes in which the tops and bottoms of 1 side of the dishes were blacked out to generate 2 contrasting light intensities. In each Petri dish, a conditioned acetate sheet was placed on the bottom. Petri dishes were exposed to sunlight to achieve 2 contrasting experimental light intensities that were similar to those recorded in intertidal habitats of Pyura chilensis: $\sim 10 \mu \mathrm{E} \mathrm{m}{ }^{2} \min ^{-1}$ (shaded section) and $\sim 1000 \mu \mathrm{E} \mathrm{m} \mathrm{m}^{-2}$ $\min ^{-1}$ (unshaded section). In order to maintain seawater temperature $\left(16 \pm 2^{\circ} \mathrm{C}\right)$, Petri dishes were immersed in a plastic tray with running seawater. After $48 \mathrm{~h}$, $P$. chilensis settlement was analysed as function of numbers in the shaded or unshaded part of the dish. The number of settlers in illuminated and shaded sections was compared using a Student's $t$-test.

Pyura chilensis field distribution. The distribution patterns of $P$. chilensis were evaluated under natural conditions at Pichilemu and Matanzas $\left(33^{\circ} 32^{\prime} \mathrm{S}\right.$, $71^{\circ} 29^{\prime} \mathrm{W}$ ) at different times from June 2002 to June 2003. We operationally grouped specimens of $P$. chilensis based on intersiphonal distance as: (a) early settlers $(\leq 0.5 \mathrm{~cm})$, (b) small specimens $(\geq 0.6$ to $\leq 1.0 \mathrm{~cm})$ and (c) large specimens $(\geq 1.0 \mathrm{~cm})$. In dense, natural aggregations of $P$. chilensis the limits between adjacent individual specimens are almost impossible to see. Therefore, in our samplings, we counted pairs of siphons clearly assigned to an individual within the aggregation. This is possible in $P$. chilensis because both siphons are clearly differentiated from the dark green tunic by their bright red colouration. In order to assess the size of the sampled specimens, we used intersiphonal distance measured with callipers to the nearest $0.1 \mathrm{~cm}$. Significant correlations between intersiphonal distance and 4 size-related variables (size, volume, weight and height; Manríquez \& Castilla 2005) strongly suggest that intersiphonal distance is a good, non-destructive method of assessing size of $P$. chilensis in the field. Small and large specimens of $P$. chilensis were counted in the low rocky intertidal fringe in 3 microhabitats with different water flow regimes and exposed to different light intensities: (1) individuals next to holdfasts of the brown kelp Lessonia nigrescens, (2) individuals in the zone between holdfasts with and (3) individuals without whiplash influence (Santelices \& Ojeda 1984). To assess the abundance of $P$. chilensis in the holdfast microhabitat, we haphazardly chose 8 (Matanzas) and 12 (Pichilemu) L. nigrescens from an intertidal platform at each locality. We counted $P$. chilensis specimens present in an area directly surrounding the holdfast in 6 quadrats of $10 \times 10 \mathrm{~cm}$. To assess abundance in the second and third microhabitats, we counted specimens in 12 quadrats of $25 \times 25 \mathrm{~cm}$, haphazardly located within each microhabitat. At both localities, quadrats were sampled along a strip transect at the same intertidal level. Numbers of $P$. chilensis recorded in the quadrats were standardised to specimens per square metre and compared between microhabitats with 1-way ANOVA, followed by TukeyKramer HSD post hoc tests. To assess the size structure with respect to each microhabitat, we measured the intersiphonal distance of 50 randomly chosen specimens within each microhabitat. To assess the abundance of settlers for each microhabitat, we removed isolated specimens and clumps of different sizes of $P$. chilensis from microhabitats near the holdfast and from the zone between holdfasts without kelp whiplash influence. Once in the laboratory we counted the number of small and large $P$. chilensis per clump and then examined their tunics under a stereomicroscope to determine the number of settlers. As before, early settlers were defined as those individuals with an intersiphonal distance $\leq 0.5 \mathrm{~cm}$.

Microhabitat stress and light intensity. To assess the physical stress associated with different water flow regimes and the mechanical disturbance associated with the 3 microhabitats described above, during low tides of September 2003, we glued (Stierling Super As epoxy for submarine application) 3 groups of 30 toothpicks ( $3 \mathrm{~cm}$ high and $0.2 \mathrm{~cm}$ width) onto an intertidal flat rock platform in Pichilemu, where Pyura chilensis normally occurs. Thirty toothpicks were assigned randomly to microhabitats that included Lessonia nigrescens holdfast zones, whiplash zones and areas 
between holdfasts with no whiplash action. After $24 \mathrm{~h}$, toothpicks were examined to determine their condition and classify them as broken or not broken. In the laboratory, we separately attached 40 toothpicks to the end of a micromanipulator and measured the average force required to break them. To assess the required force, water was added gradually to a plastic beaker hanging from the free end of each toothpick until it broke. We then estimated the corresponding breaking force (N) by multiplying the corresponding mass (g) of the water and beaker by acceleration due to gravity $\left(9.8 \mathrm{~m} \mathrm{~s}^{-2}\right)$. In order to assess light intensity, light readings were taken at 30 different points within each of the 3 microhabitats studied during low-tide periods using a Li-Cor 200 pyranometer sensor connected to a Li-Cor 1400 data logger.

Pyura chilensis field survivorship. Massive removal of Lessonia nigrescens (ca. $15 \mathrm{~m}^{2}$ ) by local fishermen during February 2003 at Pichilemu allowed us to collect field data on the effect of local hydrodynamics and light intensity on early $P$. chilensis survivorship. Harvesting $L$. nigrescens can involve either the removal of the complete plant or just removal of the stipe and blades. Complete removals can be identified by the holdfast scar on the rock. Because harvesting took place immediately after the $P$. chilensis recruitment season, we identified clumps of small $P$. chilensis associated with 3 different microhabitats: L. nigrescens holdfast scars, holdfasts without stipes and blades and unharvested plants. We chose 10 clumps of similar dimensions and from those clumps we chose 30 to 50 small specimens of different sizes ranging from 0.5 to $1 \mathrm{~cm}$ intersiphonal distance. Similarly, we chose another 5 clumps of 5 to 10 large specimens with intersiphonal distances ranging from 1.5 to $2.5 \mathrm{~cm}$. The identification and location of each ascidian in the clumps was recorded by tracing their borders onto transparent acetate sheets. Then the same clumps were revisited 1 mo later to assess individual survivorship. To compare survivorship we carried out 2-way ANOVA to determine whether the abundance differed temporally within each microhabitat and whether the abundance of each microhabitat differed between sampling episodes. Prior to analyses, the assumptions of normality and homogeneity of variance were confirmed by inspecting residuals and conducting Cochran's $C$-test, respectively.

\section{RESULTS}

\section{Chemical orientation cues}

In the first laboratory experimental design, with adult specimens of Pyura chilensis in all maze external

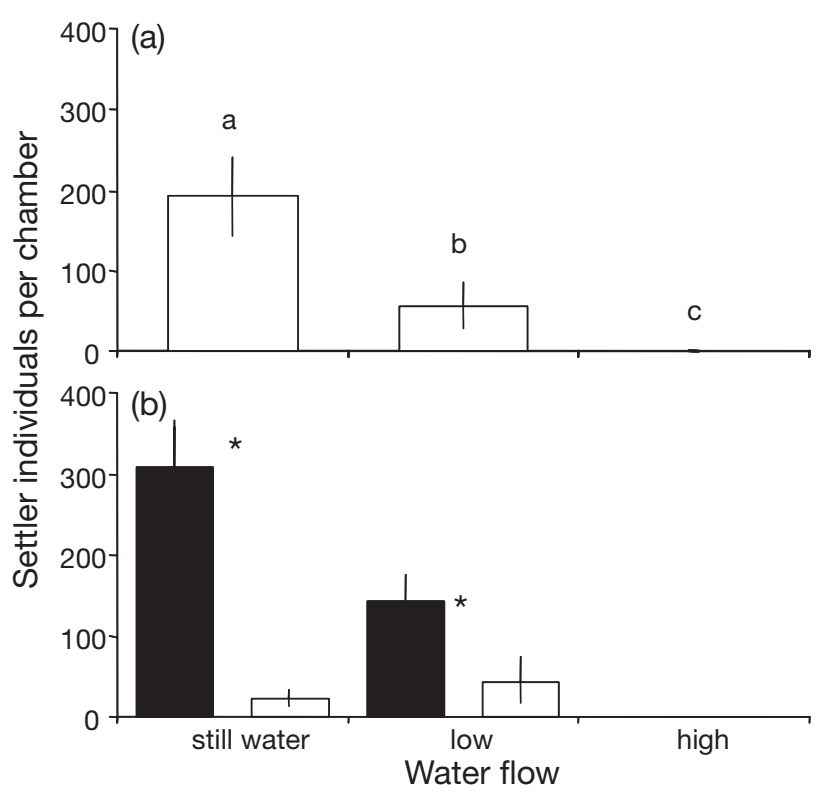

Fig. 2. Pyura chilensis. Number (mean \pm SD) of settlers recorded in the middle chambers with and without conspecifics in the external chambers and for different flow conditions. (a) In the first experiment, several adult specimens of $P$. chilensis were placed in all the external chambers of the 5 -arm maze. Means with the same letter did not differ significantly (see 'Materials and methods'). (b) In a second experiment, specimens of $P$. chilensis were placed in 3 external chambers. ${ }^{*}$ : significant differences at $\mathrm{p}<0.0001$. Filled and open bars represent settlers in chambers with and without conspecifics, respectively

sections, settlement was observed in still and low water flow regimes (Fig. 2a). A significant and negative effect of water flow on the number of settlers was found (1-way ANOVA: $\mathrm{df}_{2,43} ; F=136.69, \mathrm{p}<0.0001$ ). On average, significantly more settlers were found in the settlement chambers in still water than in low (1 to $3 \mathrm{~cm} \mathrm{~s}^{-1}$ ) flow regimes (Tukey-Kramer HSD, $\mathrm{p}<0.001$ ). No settlers were found in settlement chambers in high flow (21 to $30 \mathrm{~cm} \mathrm{~s}^{-1}$ ) experiments (Fig. 2a). In the second experiment, with high water flow, non-settlers were found irrespective of the presence of conspecific clumps (Fig. 2b), and this set of data was not included in the analysis. We found a significant effect of water flow (2-way ANOVA: $\mathrm{df}_{1,39}$ iS $=139.96, F=28.60, \mathrm{p}<$ 0.0001 ), the presence/absence of conspecifics (2-way ANOVA: $\mathrm{df}_{1,39} ; \mathrm{MS}=1271.07, F=259.70, \mathrm{p}<0.0001$ ) and the interaction of these 2 factors (2-way ANOVA: $\left.\mathrm{df}_{1,39 ;} \mathrm{MS}=170.56, F=34.85 \mathrm{p}<0.0001\right)$ on settlement (Fig. 2b). Tukey tests revealed that numbers of $P$. chilensis settlers were significantly higher in chambers near clumps of conspecifics than in empty chambers (Fig. 2b). These results were consistent between still and low water flows. 


\section{Pre-settlement period}

The number of Pyura chilensis swimming larvae (SL) with or without adult-conditioned substratum decreased exponentially with pre-settlement period (PS) (with adult-conditioned substratum, $\mathrm{SL}=69.87-17.08$ $\ln \mathrm{PS}, \mathrm{r}^{2}=0.96$; without adult-conditioned substratum, $\mathrm{SL}=48.24-17.53 \ln \mathrm{PS}, \mathrm{r}^{2}=0.87$ ). Larvae swimming $36 \mathrm{~h}$ after hatching were observed only in treatments without adult-conditioned substrata. With adult-conditioned substratum, no swimming larvae were recorded beyond $12 \mathrm{~h}$. In this treatment, a rapid reduction in the proportion of swimming larvae resulted in almost no swimming larvae after $6 \mathrm{~h}$. Significantly prolonged pre-settlement periods were recorded in treatments without adult-conditioned substratum compared to in those with adult-conditioned substratum (Fig. 3, paired $t$-test: $t=4.26, \mathrm{df}=29, \mathrm{p}<0.001$ ).

\section{Conspecifics as natural settlement substrata}

Settlement on live Pyura chilensis adults was significantly greater than on acetate sheets (Fig. 4a, 1-way ANOVA: $\mathrm{df}_{3,39 ;} F=412.73, \mathrm{p}<0.0001$ ). Although $\sim 8$ times more surface area was available for settlement on the acetate sheets, significantly more settlers were found on the surface of the ascidian tunics (Tukey-Kramer HSD, $\mathrm{p}<0.001$ ). Comparison of settlers per unit area indicated 10 times more settlers on live ascidians than on seawater-conditioned acetate sheets, and this difference was highly significant (paired $t$-test: $t=17.17, \mathrm{df}=9, \mathrm{p}<0.0001)$. As in the first experiment, the presence of dissected tunics resulted in significantly higher larval settlement (Fig. 4b, 1-way ANOVA: $\mathrm{df}_{2,28 i} F=122.09, \mathrm{p}<0.0001$ ) on the tunic surfaces than on conditioned acetate sheets (Tukey-

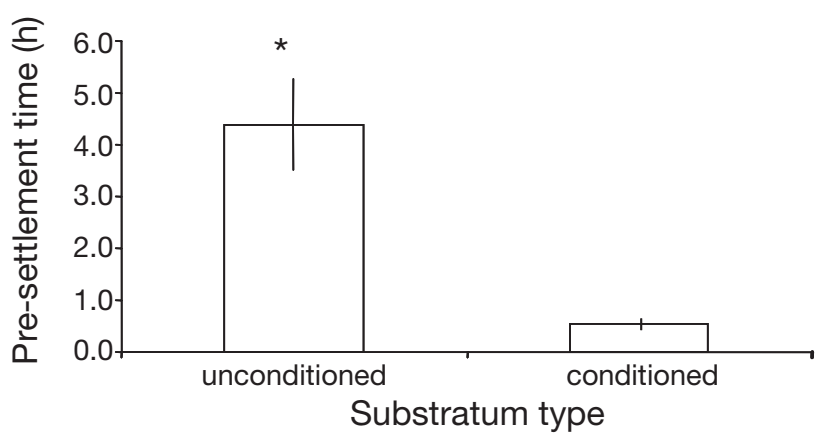

Fig. 3. Pyura chilensis. Pre-settlement duration (mean \pm SD) of larvae exposed to unconditioned and adult-conditioned substratum. In each experimental treatment measurements were conducted on 30 larvae. *: significant difference at $p<0.001$

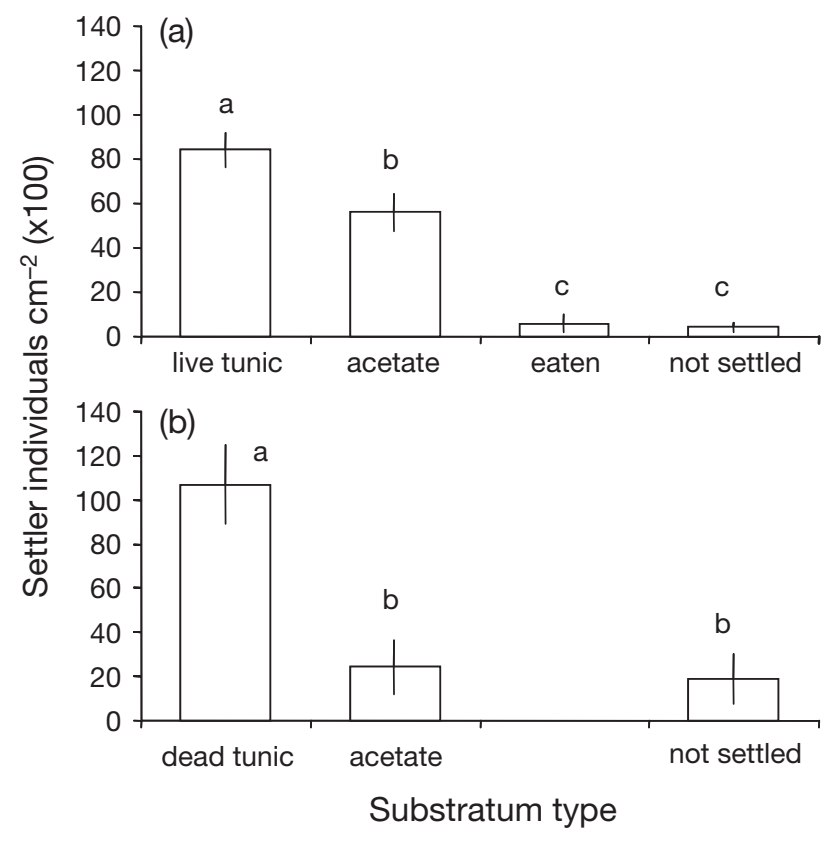

Fig. 4. Pyura chilensis. Number (mean $\pm \mathrm{SD}$ ) of settlers recorded in the presence of (a) a live adult conspecific and (b) dissected tunic of a conspecific (see 'Materials and methods').

Means with the same letter did not differ at $p<0.0001$

Kramer HSD, $\mathrm{p}<0.001)$. On average, 30 times more settlers per area were found on dissected tunics than on acetate sheets (paired $t$-test: $t=16.21, \mathrm{df}=9, \mathrm{p}<$ 0.0001).

\section{Light and larval settlement}

On average, 4 times more settlers were found in shaded than in illuminated sections of the Petri dishes, and this difference was significant (shaded $=6.20, \mathrm{SE}=$ 0.47 ; unshaded $=23.80, \mathrm{SE}=0.47, t_{48}=-26.53, \mathrm{p}<$ 0.0001).

\section{Pyura chilensis field distribution}

Regardless of sampling location, high abundances of Pyura chilensis were found near holdfasts of Lessonia nigrescens (Fig. 5, 1-way ANOVA: $\mathrm{df}_{2,93 i} F=10.93, \mathrm{p}<$ 0.0001, for Pichilemu, and 1-way ANOVA: $\mathrm{df}_{2,61} ; F=$ 7.49, $\mathrm{p}<0.0001$, for Matanzas). The Tukey HSD test indicated that at both localities the microhabitat around holdfasts had significantly higher densities of $P$. chilensis than in the kelp whiplash zone or open microhabitats. The ascidians were recorded as clumps of hundreds of small specimens around the holdfast (mean \pm SD intersiphonal distance $=1.29 \pm 0.73, \mathrm{n}=50$ ). However, large, isolated specimens were abundant in the kelp 


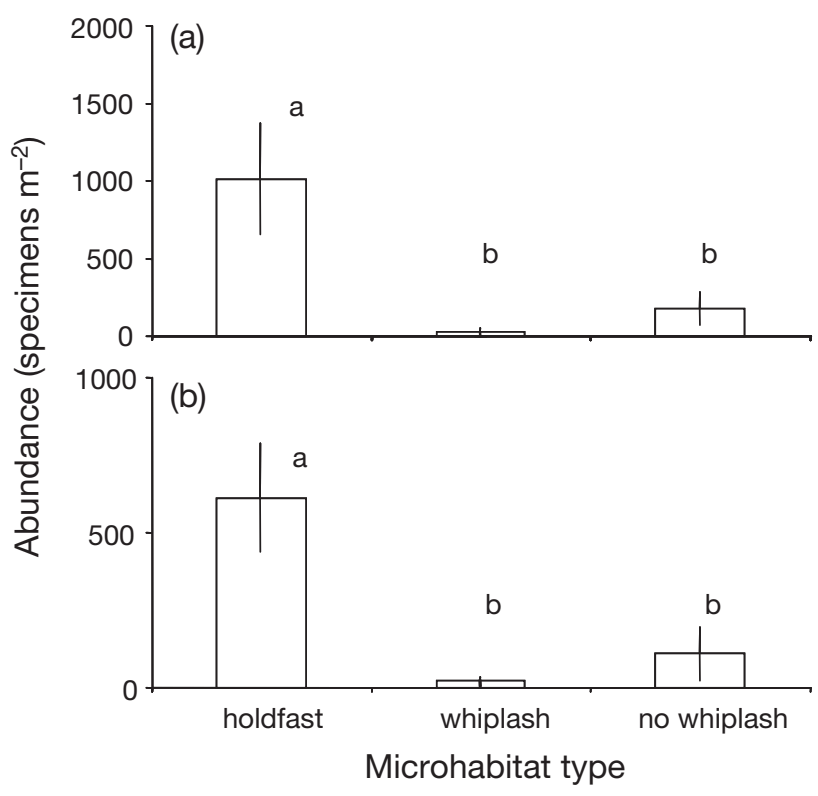

Fig. 5. Pyura chilensis. Number (mean $\pm \mathrm{SD}$ ) of specimens per microhabitat sampled: holdfast, whiplash and open areas in (a) Pichilemu and (b) Matanzas. Means with the same letter did not differ significantly at $p<0.001$

whiplash zone (mean \pm SD intersiphonal distance $=2.50$ $\pm 0.59, \mathrm{n}=50$ ) and in open microhabitats (mean \pm SD intersiphonal distance $=2.50 \pm 0.69, \mathrm{n}=50$ ). Intersiphonal distances of $P$. chilensis were significantly smaller near holdfasts than in the other 2 microhabitats (1-way ANOVA: $\left.\mathrm{df}_{2,147} ; F=54.04, \mathrm{p}<0.005\right)$. From the microhabitat near holdfasts we removed isolated specimens and clumps of up to 89 individuals. A positive and significant correlation between adult clump size (CS) and number of settlers (NS) was found $(\mathrm{NS}=0.53 \times \mathrm{CS}-1.87$, $\mathrm{r}^{2}=0.65, \mathrm{p}<0.0001$; Fig. 6). In the zone between holdfasts and without whiplash influence, maximum clump



Fig. 6. Relationships among clump size of Pyura chilensis (CS) and total number of conspecific early settlers (NS) found in the tunic of clumps sampled in microhabitats near Lessonia nigrescens holdfasts $\left(\bullet: \mathrm{NS}=0.5271 \times \mathrm{CS}-1.96767, \mathrm{r}^{2}=0.65\right.$, $\mathrm{p}<0.005)$ and microhabitats between holdfasts without whiplash influence $\left(\mathrm{O}: \mathrm{NS}=0.00866 \times \mathrm{CS}-0.2653, \mathrm{r}^{2}=0.37\right.$,

$$
\mathrm{p}<0.005)
$$

size was 23 individuals (NS $=0.00866 \times \mathrm{CS}-0.2653, \mathrm{r}^{2}=$ $0.37, \mathrm{p}<0.005$; Fig. 6 ). In this microhabitat, irrespective of clump size, 0 to 3 settlers were found on the surface of the small and large $P$. chilensis.

\section{Microhabitat stress and light intensity}

After 24 h, 6 and $11 \%$ of the toothpicks from the kelp whiplash microhabitat and the open microhabitat with no whiplash action, respectively, were broken. However, $97 \%$ of the toothpicks near holdfasts were intact. Laboratory measurements showed that the breaking forces of toothpicks ranged from 2.9 to $5.5 \mathrm{~N}$ (mean \pm $\mathrm{SD}=3.85 \pm 0.74 ; \mathrm{n}=30$ ). Light readings, measured in the field during low tides near the holdfasts, showed average values of $40 \mu \mathrm{E} \mathrm{m} \mathrm{min}^{-1}$; however, light intensities in the whiplash and open areas were 140 and $1300 \mu \mathrm{E} \mathrm{m} \mathrm{min}^{-1}$, respectively.

\section{Pyura chilensis field survivorship}

A significant effect of sampling time and microhabitat type on survival of small specimens of Pyura chilensis was observed (Fig. 7a, Table 1). Although no mortality was observed with complete kelps, significantly lower survival rates were found 1 mo later on kelps that were incompletely harvested and around kelp

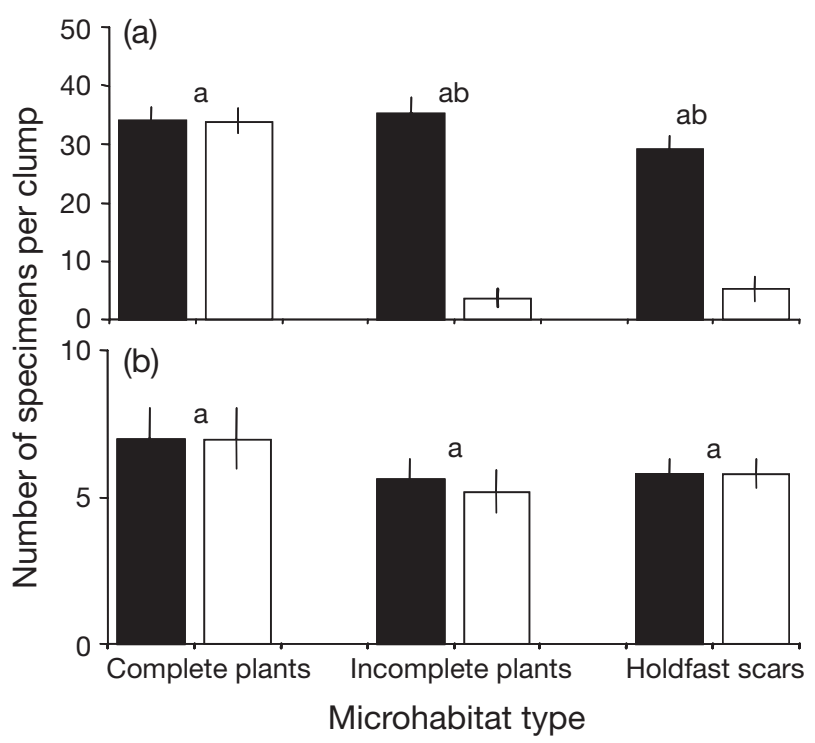

Fig. 7. Pyura chilensis. Number (mean $\pm \mathrm{SD}$ ) of (a) small and (b) large individuals of $P$. chilensis per microhabitat and over time. Specimens were sampled near complete plants of Lessonia nigrescens, near incomplete plants and near holdfast scars. Sampling was conducted just after plant harvesting (filled bars) and 1 mo later (open bars). Means with the same letter did not differ significantly at $\mathrm{p}<0.001$ 
Table 1. Pyura chilensis. Survival in the field. Results of 2-way ANOVAs on the effect of sampling time and microhabitat type on survival of small and large specimens in the field. Sampling was conducted just after Lessonia nigrescens harvesting and 1 mo later at Pichilemu, including 3 different microhabitats: L. nigrescens holdfast scars, holdfast without stipes and blades and unharvested plants. Results of pairwise comparisons with Tukey's HSD test are given at p $<0.05$ in Fig. 7

\begin{tabular}{|lccc|}
\hline & df & MS & $p$ \\
\hline Small specimens & & & \\
Time of sampling & 1 & 5227.67 & $<0.0001$ \\
Microhabitat type & 2 & 1687.62 & $<0.0001$ \\
$\begin{array}{l}\text { Time of sampling } \times \\
\quad \text { Microhabitat type }\end{array}$ & 2 & 1339.12 & $<0.0001$ \\
Residual & 54 & 47.64 & \\
Large specimens & & & \\
Time of sampling & 1 & 6.93 & $>0.05$ \\
$\begin{array}{l}\text { Microhabitat type } \\
\text { Time of sampling } \times\end{array}$ & 2 & 0.13 & $>0.05$ \\
$\quad$ Microhabitat type & 2 & 0.13 & $>0.05$ \\
Residual & 24 & 2.9 & \\
\hline
\end{tabular}

holdfast scars (Tukey-Kramer HSD, p < 0.001). A 2way ANOVA did not determine any significant effect of sampling time or type of microhabitat on survival of large specimens of $P$. chilensis (Fig. 7b, Table 1).

\section{DISCUSSION}

Larval response to the presence of established conspecific adults has been reported for numerous invertebrate groups (Pawlik 1992). Our laboratory experiments show high Pyura chilensis larval settlement on live or dead adult conspecific ascidians and on dead tunics (Figs. 2b \& 4), suggesting that larvae of this species respond behaviourally to waterborne cues associated with conspecifics. This settlement behaviour may explain the positive association found in the field among established clumps of adult $P$. chilensis and conspecific settlers (Davis 1987, present study) and is consistent with previous studies in ascidians (Svane et al. 1987). Still-water laboratory assays have reported active invertebrate larval selection and passive entrapment on bacterial biofilm (Wieczorek \& Todd 1997). Our experiments also showed that $P$. chilensis larval settlement occurred on acetate sheets (but at a significantly lower rate than on live or dead tunics), in experimental beakers containing live and dead ascidians (Fig. 4). Therefore, a settlement response to bacterial biofilms developed during the experiment cannot be ignored.

The temporal and spatial scales at which conspecific waterborne extract is useful in generating preferential larval settlement in Pyura chilensis are unknown. The factors affecting the distribution of chemical stimuli in the sea vary with spatial and temporal scales (Atema 1988). Therefore, given the inevitable dilution of chemical stimuli in the sea, we would argue that this behavioural response is only likely to be useful on scales of centimetres and time periods of seconds, near physically protected microhabitats inhabited by adult conspecifics. The presence of $P$. chilensis in more exposed microhabitats, such as kelp holdfasts and crevices, suggests that some larvae of $P$. chilensis may be less selective at settlement. This pattern is consistent with the hypothesis that larvae become less selective and more desperate as they develop, resulting in acceptance of sub-optimal sites for settlement (KnightJones 1951). However, alternatives to the desperate larva hypothesis have been proposed based on laboratory experiments with polychaete larvae (Toonen \& Pawlik 2001). Future studies are needed to test whether the desperate larva hypothesis is important in the settlement of $P$. chilensis.

In our experiments, Pyura chilensis larvae displayed chemically cued positive rheotaxis only in weak flows (1 to $3 \mathrm{~cm} \mathrm{~s}^{-1}$ ). Failure to settle in high flows (21 to $30 \mathrm{~cm} \mathrm{~s}^{-1}$ ) in the laboratory suggests that $P$. chilensis larvae settle in the rocky intertidal under benign flow conditions. This conclusion is consistent with other studies on the effects of water movement on settlement behaviour of invertebrate larvae (Abelson \& Denny 1987, Havenhand \& Svane 1991). A similar linkage has been reported between weak flows (ca. $20 \mathrm{~cm} \mathrm{~s}^{-1}$ ) and settlement of bryozoan larvae in subtidal crevices and around holdfasts of Lessonia trabeculata (Muñoz 1991). Thus, microhabitat heterogeneity over small scales may play an important role in the establishment of intertidal populations of $P$. chilensis. The surfaces of marine substrata such as kelp stipes, algal turf, algal canopies, coral branches, rocks and other protruding bodies alter water flow patterns and light regimes (Abelson \& Denny 1987). In intertidal habitats, Lessonia nigrescens protrudes above the bottom and may therefore modify local water flow and larval settlement. Although the holdfast in this species is large and smooth, it usually has many cavities that support a diverse invertebrate assemblage (Cancino \& Santelices 1984). Simple models of flow in the vicinity of a cylinder predict a flow deceleration downstream of the body (Abelson \& Denny 1987); however, this model also predicts that most propagule encounters with the substrata occur when water flows over the cylinder and into depressions such as pits and crevices (Abelson \& Denny 1987). By the time water flows through the kelp canopy and over the holdfast, velocity has been reduced enough to allow $P$. chilensis larvae to settle. In Chile, extensive intertidal areas of $L$. nigrescens are 
harvested by hand for alginates (Vásquez \& Santelices 1990), which could explain the low intertidal abundances of $P$. chilensis. Because not all ascidian species are specialised for higher rates of suspension feeding and early growth (Sherrard \& LaBarbera 2005), settlement of $P$. chilensis in hydrodynamically protected microhabitats with low water flow may improve early adhesion, feeding efficiency, growth and longevity. Larvae of specialist marine herbivores respond to and are retained close to waterborne cues from the adult host algae (Krug \& Zimmer 2000). Experiments to test the role of the kelp holdfast in settlement were not evaluated in the present study. Therefore, the potential role played by waterborne cues originating from the kelp holdfast should be addressed in future studies.

Our study suggests that water flow is not the only important determinant of Pyura chilensis larval settlement and the establishment of their intertidal population. We observed high abundances of adults and settlers of $P$. chilensis near kelp holdfasts and few settlers in more exposed microhabitats, such as inter-holdfast areas with and without whiplash. Similarly, a recent study reported that settlement of $P$. chilensis on artificial settlement substrata deployed $1 \mathrm{~m}$ below the water surface was strongest where disturbance frequencies were low (Valdivia et al. 2005). Differences in survivorship for newly settled specimens in microhabitats with different physical disturbance and illumination regimes also suggest that these variables play an important role in the early establishment of $P$. chilensis. Wave-induced whiplash in kelp has been reported as a mechanism of intraspecific interference that produces a recruitment area with reduced grazing pressure and reduced interference by adult fronds (Santelices \& Ojeda 1984), and interference by adult kelp fronds could also be important in regulating settlement and establishment of intertidal populations of $P$. chilensis. Therefore, low losses of toothpicks near Lessonia nigrescens holdfasts suggest a microhabitat with low physical disturbance compared to the kelp whiplash and open areas. Water movement is essential for suspension feeders such as hydroids, bryozoans, sponges, amphipods and ascidians, in order to supply adequate food, remove metabolic waste products, prevent accumulation of sediment and disperse larvae. Therefore, the fact that only adult $P$. chilensis can persist after L. nigrescens holdfasts have been harvested suggests mortality related to differences in adhesive capacity or feeding efficiency related to ascidian size. Water movement can impose substantial microhabitat hydrodynamic forces and play an important role in survivorship and patch dynamics (for reviews, see Denny et al. 1985). Maximum drag forces measured in waveexposed central Chilean rocky intertidal areas are about $14 \mathrm{~N}$ (see Castilla et al. 1998), almost 3 times the force needed to break the toothpicks. We suggest that the drag and lift forces characteristic of the central Chile rocky intertidal are reduced in microhabitats such as in rock crevices and the surroundings of L. nigrescens holdfasts. In the rocky intertidal zone, water velocities vary over the course of a tidal cycle (Heiss et al. 2000). Although water velocities around L. nigrescens are unknown, measurements inside and outside the canopies of the small intertidal seagrass Zostera novazelandica and the large subtidal kelp Lessonia trabeculata clearly suggest that algae may significantly reduce the water flow around them (Muñoz 1991, Heiss et al. 2000). Therefore, opportunistic settlement in those microhabitats, cued by factors such as shading, the presence of conspecifics, and low physical disturbance should increase early survival of $P$. chilensis. This conclusion is consistent with the positive correlation between adult $P$. chilensis clump size and number of conspecific settlers near L. nigrescens holdfasts. Differences in the ability of predators to catch and hold individual mussels based on their position relative to the bed edge affects mussel survivorship (Svane \& Ompi 1993). This variability in predation may be another potential advantage of gregarious settlement in $P$. chilensis.

On large spatial scales, currents and near-bottom dynamics affect larval dispersal and settlement (Butman 1987). However, on smaller spatial scales when larvae approach the substratum, behavioural responses of larvae to chemical and biological cues appear to be more important (Kingsford et al. 2002). In general, our results suggest that in the intertidal zone of central Chile, gregarious settlement of Pyura chilensis is the result of both biological and environmental parameters, which is in agreement with similar results reported for other ascidians (Havenhand \& Svane 1991, Davis 1996). Our results suggest that light may regulate settlement through negative phototaxis at the time of settlement. This taxis has been described for other ascidian larvae (Svane 1987), and may be a mechanism to avoid post-settlement mortality due to excessive exposure to light. The positive effect of the laboratory shaded substratum and the abundance of settlers of $P$. chilensis is consistent with the association between intertidal population of this species and shaded areas around the holdfast of Lessonia nigrescens. During low tide the substrate near L. nigrescens can be exposed to air for 3 to $4 \mathrm{~h}$; therefore, the shaded, damp areas around the holdfasts provide a benign microhabitat with reduced physiological stress, thereby improving survivorship. A positive larval settlement response to conspecific waterborne cues and adult-conditioned substrates, coupled with differential microhabitat flow regimes and physical disturbance, may lead to increased larval settlement pool on suitable substra- 
tum. This response could explain the aggregated distribution pattern of $P$. chilensis near L. nigrescens holdfasts in intertidal habitats. In subtidal, hard-bottom habitats, where physical processes are smaller in magnitude, patterns of distribution and abundance in $P$. chilensis are more likely to be determined by biological interactions (see Valdivia et al. 2005) such as predation or competition for space. However, subtidal observations (J. C. Castilla pers. obs.) suggest that crevices and holdfasts of the kelp Lessonia trabeculata and other protruding bodies can also aggregate subtidal distribution of $P$. chilensis.

Establishment of marine reserves has been proposed to protect Pyura chilensis against overexploitation (Davis 1995). This ascidian supports a fraction of the Chilean artisanal fishery and, as with other members of the genus Pyura, acts as a habitat engineer by hosting an important associated community of micro- and macroinvertebrates (see Zamorano \& Moreno 1975, Sepúlveda et al. 2003, Castilla et al. 2004). Therefore, the removal of $P$. chilensis may have a negative effect on their natural populations and through a cascading effect on the associated community. Given that population dynamics of short-distance dispersers are largely attributed to patterns of larval supply (Keough \& Chernoff 1987), closing the fishery during the recruitment season and leaving a proportion of the adult stock on the fishing grounds will facilitate self-seeding and provide a management strategy that should benefit $P$. chilensis and other species with similar life histories.

Acknowledgements. This research was funded by the Fondecyt Grant No. 3020035 to P.H.M. We sincerely appreciate field and laboratory help provided by M. E. Jara. Supplementary funding from an A. Mellon Foundation grant to J.C.C. and S. A. Navarrete and the project FONDAP-Fondecyt 15010001 (Project No. 6) to the Center for Advanced Studies in Ecology \& Biodiversity allowed important improvements to be made to the Las Cruces (ECIM) laboratories in support of the present study. The final version of this manuscript was completed during the tenure of Fondecyt Project 1050841 (P.H.M.). Much appreciation goes to M. Lee for improving the English and to N. Lagos for assistance in the analyses. Four anonymous reviewers made very helpful suggestions.

\section{LITERATURE CITED}

Abelson A, Denny M (1987) Settlement of marine organisms in flow. Annu Rev Ecol Syst 28:317-339

Ambler RP, Cañete JI (1991) Asentamiento y reclutamiento de Pyura chilensis Molina, 1782 (Urochordata: Ascidiacea) sobre placas artificiales suspendidas en Bahía La Herradura, Coquimbo, Chile. Rev Biol Mar 26:403-413

Atema J (1988) Distribution of chemical stimuli. In: Atema J, Fay RR, Popper AN, Tavolga (eds) Sensory biology of aquatic organisms. Springer-Verlag, Berlin, p 29-56

Butman CA (1987) Larval settlement of soft-sediment invertebrates: the spatial scales of pattern explained by active habitat selection and the emerging role of hydrodynamic process. Oceanogr Mar Biol Annu Rev 25:113-165

Cancino J, Santelices B (1984) Importancia ecológica de los discos adhesivos de Lessonia nigrescens Bory (Phaeophyta) en Chile central. Rev Chil Hist Nat 57:23-33

Castilla JC (1981) Perspectivas de investigación en estructura y dinámica de comunidades intermareales rocosas de Chile central. II. Depredadores de alto nivel trófico. Medio Ambiente 5:190-215

Castilla JC, Defeo O (2001) Latin American benthic shellfisheries: emphasis on co-management and experimental practices. Rev Fish Biol Fish 11:1-30

Castilla JC, Steinmiller DK, Pacheco CJ (1998) Quantifying wave exposure daily and hourly on the intertidal rocky shore of central Chile. Rev Chil Hist Nat 71:19-25

Castilla JC, Lagos NA, Cerda M (2004) Marine ecosystem engineering by the alien ascidian Pyura praeputialis on a mid-intertidal rocky shore. Mar Ecol Prog Ser 268:119-130

Cea G (1969) Estadios primarios de desarrollo y metamorfosis de Pyura chilensis Molina, 1782 (Tunicata, Ascidiacea, Pyuridae). Bol Soc Biol Concepción 42:317-331

Daume S, Brand-Gardner S, Woelkerling WJ (1999) Settlement of abalone larvae (Haliotis laevigata Donovan) in response to nongeniculate coralline red algae (Corallinales, Rhodophyta). J Exp Mar Biol Ecol 234:125-143

Davis AR (1987) Variations in recruitment of the subtidal colonial ascidians Podoclavella cylindrical (Quoy \& Gaimard): the role of substratum choice and early survival. J Exp Mar Biol Ecol 106:57-71

Davis AR (1995) Over-exploitation of Pyura chilensis (Ascidiacea) in southern Chile: the urgent need to establish marine reserves. Rev Chil Hist Nat 68:107-116

Davis AR (1996) Association among ascidians: facilitation of recruitment in Pyura spinifera. Mar Biol 126:35-41

Denny MW, Daniel TL, Koehl MAR (1985) Mechanical limits to size in wave-swept organisms. Ecol Monogr 55:69-102

Gosselin LA, Qian PY (1997) Juvenile mortality in benthic marine invertebrates. Mar Ecol Prog Ser 146:265-282

Havenhand JN, Svane I (1991) Roles of hydrodynamics and larval behaviour in determining spatial aggregation in the tunicate Ciona intestinalis. Mar Ecol Prog Ser 68:271-276

Heiss WH, Smith AM, Probert PK (2000) Influence of the small intertidal seagrass Zostera novazelandica on linear water flow and sediment texture. NZ J Mar Freshw Res 34: 689-694

Hunt HL, Scheibling RE (1997) The role of early postsettlement mortality in recruitment of benthic marine invertebrates: a review. Mar Ecol Prog Ser 155:269-301

Keough MJ, Chernoff H (1987) Dispersal and population variation in the bryozoan Bugula neritina. Ecology 68:199-210

Kingsford MJ, Leis JM, Shanks A, Linderman KC, Morgan SG, Pineda J (2002) Sensory environments, larval abilities and local self-recruitment. Bull Mar Sci 70:309-340

Knight-Jones EW (1951) Gregariousness and some other aspects of the settling behaviour of Spirorbis. J Mar Biol Assoc UK 30:201-222

Knight-Jones EW (1955) The gregarious settling reaction of barnacles as a measure of systematic affinity. Nature 175: 266

Krug PJ, Zimmer RK (2000) Larval settlement: chemical markers for tracing production, transport, and distribution of a waterborne cue. Mar Ecol Prog Ser 207:283-296

Legendre P, Legendre L (1998) Numerical ecology. Development in environmental modelling, Vol 20. Elsevier, Amsterdam

Manríquez PH, Castilla JC (2005) Self-fertilization as an alternative mode of fertilization in the solitary tunicate Pyura chilensis. Mar Ecol Prog Ser 301:113-125 
Muñoz MR (1991) Factores que explican la diversidad alfa en comunidades de briozoos incrustantes de Chile central. PhD thesis, Pontificia Universidad Católica de Chile, Santiago de Chile

Pawlik JR (1992) Chemical ecology of the settlement of benthic marine invertebrates. Oceanogr Mar Biol Annu Rev 30:273-335

Pearce CM, Scheibling RE (1990) Induction of settlement and metamorphosis in the sand dollar Echinaranchnius parma: evidence for an adult-associated factor. Mar Biol 107: 363-369

Ryland (1974) Behaviour, settlement and metamorphosis of bryozoan larvae: a review. Thalassia Jugosl 10:239-262

Santelices B, Ojeda FP (1984) Recruitment, growth and survival of Lessonia nigrescens (Phaeophyta) at various tidal levels in exposed habitats of central Chile. Mar Ecol Prog Ser 19:73-82

Sepúlveda R, Cancino JM, Thiel M (2003) The peracarid epifauna associated with the ascidian Pyura chilensis (Molina, 1782) (Ascidiacea: Pyuridae). J Nat Hist 37: 1555-1569

Sherrard KM, LaBarbera M (2005) Form and function in juvenile ascidians. I. Implications of early juvenile morphologies for performance. Mar Ecol Prog Ser 287:127-138

Svane I (1987) On larval behaviour and post-metamorphic mortality of Ascidea metula OF Müller. Ophelia 27:87-100

Svane I, Ompi M (1993) Match dynamics in the beds of the mussel Mytilus edulis: effect of site, patch size and position within a match. Ophelia 37:187-202

Svane IB, Young CM (1989) The ecology and behavior of ascidian larvae. Oceanogr Mar Biol Annu Rev 27:45-90

Svane I, Havenhand JN, Jørgensen AJ (1987) Effects of tissue extracts of adults on metamorphosis in Ascidia mentula

Editorial responsibility: Otto Kinne (Editor-in-Chief), Oldendorf/Luhe, Germany
OF Müller and Ascidiella scabra (OF Müller). J Exp Mar Biol Ecol 110:171-181

Toonen RJ, Pawlik JR (2001) Settlement of the gregarious tube worm Hydroides dianthus (Polychaeta: Serpulidae). II. Testing the desperate larva hypothesis. Mar Ecol Prog Ser 224:115-131

Valdivia N, Heidemann A, Thiel M, Molis M, Wahl M (2005) Effects of disturbance on the diversity of hard-bottom macrobenthic communities on the coast of Chile. Mar Ecol Prog Ser 299:45-54

Vásquez E, Young CM (1996) Responses of compound ascidian larvae to haloclines. Mar Ecol Prog Ser 133:179-190

Vásquez JA (1983) Pyura chilensis Molina, 1782 en el Norte del Perú (Ascidiacea, Pyuridae). Bol Biol Concepción 54: $171-172$

Vásquez J, Santelices B (1990) Ecological effects of harvesting Lessonia (Laminariales, Phaeophyta) in central Chile. Hydrobiologia 204:41-48

Walter LJ, Wethey DS (1996) Settlement and early postsettlement survival of sessile marine invertebrates on topographically complex surface: the importance of refuge dimensions and adult morphology. Mar Ecol Prog Ser 137:161-171

Wieczorek SK, Todd CD (1997) Inhibition and facilitation of bryozoan and ascidian settlement by natural multi-species biofilms: effects of film age and roles of active and passive larval attachment. Mar Biol 128:468-473

Young CM (1988) Ascidian cannibalism correlates with larval behavior and adult distribution. J Exp Mar Biol Ecol 117:9-26

Zamorano JH, Moreno CA (1975) Comunidades bentónicas del sublitoral rocoso de Bahía Corral. I. Area mínima de muestreo y descripción cuantitativa de la asociación Pyura chilensis Molina. Medio Ambiente 1:58-67

Submitted: January 5, 2006; Accepted: August 8, 2006 Proofs received from author(s): February 19, 2007 